\title{
The Effect of Egg White and Honey Intervention in TB Patients Towards Blood Pressure and Hb Levels
}

\author{
Putri Aulia Arza ${ }^{1}$, Dezi Ilham ${ }^{2}$, Fitri Anggraini ${ }^{3}$ \\ \{tilla.arza@gmail.com\} \\ ${ }^{1}$ Andalas University, Indonesia, ${ }^{2}$ STIKes Perintis Padang, Indonesia, ${ }^{3}$ RSUD M.Zein, Padang, Indonesia
}

\begin{abstract}
Tuberculosis (TB) is a leading cause of morbidity and mortality worldwide. Considering albumin function of the body is very important, a food survey should be done to understand what kind of food can increase albumin in tuberculosis patients. In this survey, patients were given egg white extract with honey. The purpose of this research was to assess the effectivity of egg white extract with honey intake on blood pressure dan $\mathrm{Hb}$ level. A single-blind randomized controlled trial was conducted at DR. M. Zein hospital in 2018 (895.6/034/RSUD/2019). Sampling technic used purposive sampling, and 32 patients were allocated to intervention $(n=16)$ and control $(n=16)$ groups. Both groups received high energy high protein diet; the intervention group received an oral egg white extract with honey for seven days. Data were analyzed using a paired-sample t-test to analyze before-after differences in blood pressure dan $\mathrm{Hb}$ level between. Wilcoxon Sign Rank test was used to assess the differences between the two groups. The average blood pressure and blood pressure before study in the intervention group, respectively, was $125 / 81$ $\mathrm{mmHg}$ and $11, \mathrm{~g} / \mathrm{dL}$ eight, and that in the control group was 114,06/75,13 and $10,99 \mathrm{mmHg}$. The average after study in the intervention group was 109/ $71 \mathrm{mmHg}$ and 12,8 , and that in the control group was $119 / 78$ and 11,3 . Bivariate analysis showed that there was a significant difference in the increase of blood pressure and $\mathrm{Hb}$ level between intervention groups with $\mathrm{p}=0.001(\mathrm{p}<0.05)$. Meanwhile, there was no significant difference in the increase of blood pressure and $\mathrm{Hb}$ level between control groups with $\mathrm{p}=0.5(\mathrm{p}>0.05)$. Egg white effectively increased blood pressure and $\mathrm{Hb}$ level in the intervention group.
\end{abstract}

Keywords: blood pressure, Egg White, Hb Level, tuberculosis

\section{Introduction}

Tuberculosis (TB) is one of the ten highest causes of death in the world, about 2 billion people or $1 / 3$ of the world's population. Based on data from the World Health Organization (WHO), the number of pulmonary TB cases in 2015 reached 10.4 million people, an increase from the previous 9.6 million. Based on data and information on Indonesia's health profile in 2015 , the number of cases of pulmonary TB as many as 330,910 cases increased compared to 2014 as many as 324,539 cases. At the level of West Sumatra from the results of the survey data and health profile information in 2016 , there were 6,188 cases of pulmonary TB with 
positive AFB as many as 3,847 cases. The South Coastal District based on health profiles in 2015 were 573 cases with AFB positive.

Tuberculosis (TB) is a leading cause of morbidity and mortality worldwide. As per the World Health Organization (WHO), around 1.8 million people have died due to tuberculosis in 2013 [2]. Considering albumin function of the body is very important, a food survey should be done to understand what kind of food which can increase albumin in tuberculosis patients. Egg white protein is a high-quality and complete food source [1]. In this research, patients were given egg white with honey.

Tuberculosis transmission occurs because germs are coughed or cleaned into the air by patients with active pulmonary TB becoming infections. If healthy people inhale the infection particles, they will stick to the airway of the lungs. Approximately $30 \%$ of people who have interacted with active pulmonary TB sufferers will also be infected with pulmonary TB, further development of TB germs depends on the host's immune system (Peloquin, 2002).

The administration of pulmonary medicine is given in the form of a combination of several types of drugs, including anti-TB drugs (OAT) and combination drugs (FDC), in which the administration of these drugs will cause various kinds of complaints during the treatment process. So that nutritional therapy is also one of the main supporting factors in healing. Eggs are a food that has a high protein content. Eggs are a source of animal protein that is needed by the body to maintain the body's metabolism. It is because the complete nutritional content makes many eggs consumed and processed. Egg white is a food that is easy and inexpensive to obtain, has a high biological value. Egg white protein content of $10.3 \mathrm{gr} /$ 100 gr. Eggs also contain more than $90 \%$ calcium and iron. Iron can replace lost blood (Supriati, 2015). So that egg whites are best given to pulmonary TB patients who need foods high in protein. The research toward adults aged over 18 years stated that the effect of egg white juice administration on HB levels in pulmonary TB patients is characterized by a value of $p<0.05(p=0.0001)$ [5]. This research was conducted for seven days. In addition, prevention and monitoring of blood pressure to be stable can also be done by providing protein levels. So, it is given a high calorie and high protein meal (Nainggolan et al., 2012).

Honey also has a high-calorie content of $328 \mathrm{cal}$ and protein of $0.5 \mathrm{gr}$. According to Dr. Stavia Turyanable in the 80 s, a researcher from the TB Control Center that honey can act as anti-tuberculosis prevention that is involved in dietary therapy in healing patients. Honey has a chemical component that has a coligemic effect, namely acetylcholine, which functions to improve blood circulation and reduce blood pressure. High sugar content in honey can increase endurance to fight some complaints in pulmonary TB patients, such as the body feels weak and decreased appetite. Rahma's (2013) study which states that regular administration of juice and honey can reduce blood pressure marked by a p-value $<0.005$.

RSUD Dr. M. Zein Painan is one of the hospitals located in West Sumatra, precisely in the South Coastal District. Where Based on data from 10 diseases, most inpatients, there is an increase in the incidence of pulmonary TB from 2016 -2017. Lung Irna RSUD Dr. M. Zein Painan was only established in May 2015, from year to year there has always been an increase, as evidenced in 2017, it increased to 8th out of the indicator of the ten most inpatients of $4.29 \%$.

Based on the above, the authors are interested in carrying out other studies on the effect of giving extra egg whites and honey on blood pressure, and hemoglobin levels in pulmonary TB patients in Dr.M.Zein Painan Regional Hospital in 2018.

The purpose of this study is the purpose of this research was to assess the effectivity of egg white extract with honey intake on blood pressure dan $\mathrm{Hb}$ level 


\section{Method}

A single-blind randomized controlled trial was conducted at DR. M. Zein hospital in 2018. Sampling technic used purposive sampling, and 32 patients were allocated to intervention $(\mathrm{n}=16)$ and control $(\mathrm{n}=16)$ groups. Both groups received high energy high protein diet. The intervention group received an oral egg white extract with honey for seven days. The Egg white is given twice times a day (Martony, 2005) with an average weight of 1 egg white $=46.5 \mathrm{gr}$, egg whites are processed by steaming. Then an addition of $20 \mathrm{ml}$ honey (2 tablespoons) twice a day separately (Ollusula et al, 2012), so that in a day honey is given as much as $40 \mathrm{ml}$ (4 tablespoons). Data were analyzed using a paired sample t-test to analyze before-after differences in blood pressure dan $\mathrm{Hb}$ level between. Wilcoxon Sign Rank test was used to assess the differences between two groups.

\section{Results}

The effect of egg white and honey intervention significantly increase blood pressure pvalue $=0,0001(\mathrm{p}, 0.05)$. meanwhile, there was not significant difference in control groups with $\mathrm{p}=0.092(\mathrm{p}>0.05)$ (figure 1$)$.

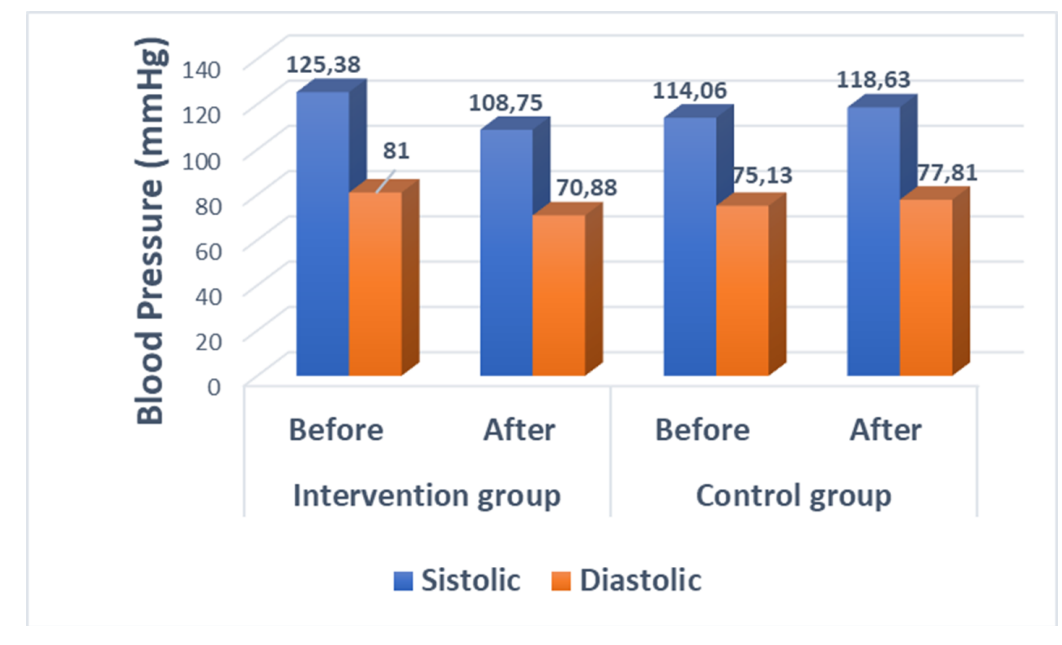

Figure 1. The effect of egg white and honey intervention on blood pressure

The effect of egg white and honey intervention significantly increases HB levels p-value $=$ $0,0001(\mathrm{p}, 0.05)$. meanwhile, there was no significant difference in control groups with $\mathrm{p}=$ $0,386(\mathrm{p}>0.05)$ (Figure 2). 


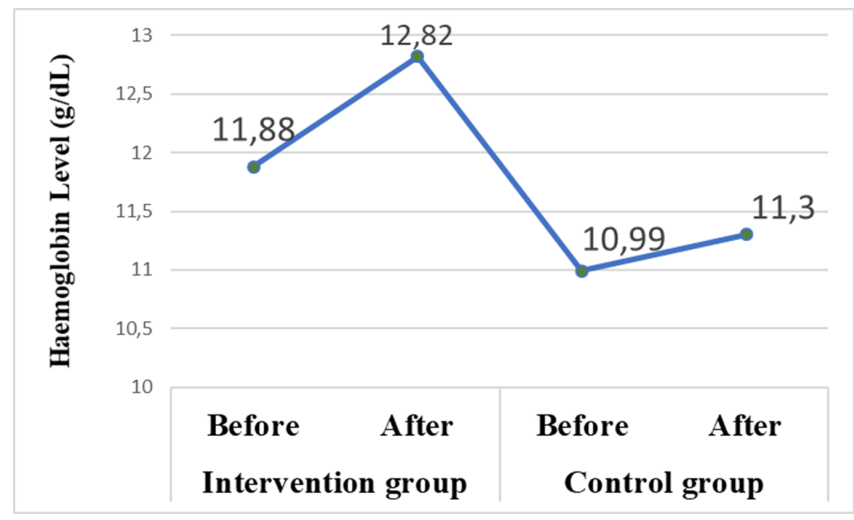

Figure 2. The effect of egg white and honey intervention on $\mathrm{Hb}$ Level

\section{Discussion}

\subsection{The Influence of White Eggs Added Honey to Blood Pressure}

Based on the results of the study, it was found that after consumption of egg white with honey, the average systolic blood pressure in the intervention group was 108.75, and diastolic was 70.88. Whereas in the control group, the average systolic blood pressure was 118.63 , and the diastolic blood pressure was 77.81. This result support by researchers that found eggs that produce proteins that have the same effect as blood pressure-lowering drugs. They also found eggs that can lower blood pressure in the same way as ACE inhibitors (Angiotensin Conversion Enzymes) [4]. It also contradicts research conducted by Jafar, et al. (2017), who discovered the decrease in systolic and diastolic blood pressure after honey administration [3].

\subsection{The Influence of White Eggs Added Honey to Hb Level}

The result shows that the treatment group the paired samples T-test results (T-Test) obtained $p=0.001(p<0.05)$. It means that Ho was rejected, and Ha was accepted, which was the effect of giving extra egg white and honey to HB levels in pulmonary TB patients. This relates to the results of the research Syamsiatun, which states that the administration of egg white juice on $\mathrm{Hb}$ levels [5]. Whereas in the control group, the paired samples T-test results ( $p$-test) obtained $p=0.386(p>0.05)$ means that Ho is accepted, and Ha is rejected, i.e., there is no effect of giving extra egg white and honey to Hb levels in TB patients lung. 


\section{Conclusion}

The results of blood pressure measurements before treatment in the case group mean systolic blood pressure is 125.38 , and diastolic is 81.0. Whereas in the control group, the average systolic blood pressure in the control group was 114.06, and the diastolic blood pressure was 75.13 .

The results of the measurement of HB levels before treatment the average HB level in the case group was 11.88, with a standard deviation value of 1.284 , and the HB level was ten, and the highest was 14. While in the control group, the average HB level was 10.99 with a value of the standard deviation of 1.898, and the lowest HB level is eight, and the highest is 14. Egg white effectively increased blood pressure and $\mathrm{Hb}$ level in the intervention group.

\section{Acknowledgments}

Credits are given to the RSUD M. Zein staff, who had helped the process of research.

\section{References}

[1] Lotfian, F., Emam Djomeh, Z., Karami, M., \& Moeini, S. (2019). Protein beverages made of a mixture of egg white and chocolate milk: Microbiology, nutritional and sensory properties. Food science \& nutrition, 7(4), 1466-1472.

[2] World Health Organization. (2013). Global tuberculosis report 2013. World Health Organization.

[3] Jafar, N., Hamid, S. K., Citrakesumasari, C., Najamuddin, U., \& Syam, A. (2017). Khasiat madu menurunkan tekanan darah dan hematologi parameter. Media Kesehatan Masyarakat Indonesia, 13(1), 27-33.

[4] Manso, M. A., Miguel, M., Even, J., Hernández, R., Aleixandre, A., \& López-Fandiño, R. (2008). Effect of the long-term intake of an egg white hydrolysate on the oxidative status and blood lipid profile of spontaneously hypertensive rats. Food chemistry, 109(2), 361-367.

[5] Syamsiatun, N. H., \& Siswati, T. (2015). Pemberian ekstra jus putih telur terhadap kadar albumin dan $\mathrm{Hb}$ pada penderita hipoalbuminemia. Jurnal Gizi Klinik Indonesia, 12(2), 54-61. 